\title{
"How many sums can I do"? \\ Performative strategies and diffractive thinking as methodological tools for rethinking mathematical subjectivity
}

\author{
Anna Palmer \\ Stockholms Universitet, SE-106 91 Stockholm, Sweden \\ Anna.palmer@buv.su.se
}

\begin{abstract}
The aim of this article is to illustrate how the understanding of mathematical subjectivity changes when transiting theoretically and methodologically from a discursive and performative thinking, as suggested by Judith Butler (1990, 1993, 1997), to an agential realist and diffractive thinking, inspired by Karen Barad's theories $(2007,2008)$. To show this I have examined narrative memory stories about mathematics written by students participating in Teacher Education maths courses. I provide examples of such stories and present an in-depth analysis of one such story. The first part of the analysis has been carried out using performative methodological strategies - in relation to Judith Butler's theories - while the latter part of analysis has been performed with the aid of diffractive methodological thinking - in relation to Barad's theoretical perspectives. When summarising the different analyses, it becomes evident that the understanding of data - and of me as researcherchanges when transiting from one theoretical and methodological arena to another. Depending on which questions we pose, what methodological strategies we use, and which theoretical fields we get involved in, we would see and understand this differently.
\end{abstract}

\section{Introduction}

The aim of this article is to illustrate how the understanding of mathematical subjectivity changes when transiting theoretically and methodologically from a discursive and performative thinking, as suggested by Judith Butler $(1990,1993,1997)$, to an agential realist and diffractive thinking, inspired by Karen Barad's theories $(2007 ; 2008)$. In relation to this aim, what is it to theorise around your data? What does it mean to actually install oneself as researcher in a theoretical field and perform an analysis of data with the support of the concepts and theoretical tools available there? And what happens to my understanding of data - and to me as researcher - when transiting from one theoretical and methodological arena to another? These are questions I have been engaged with in the writing of this article about the constitution of mathematical subjectivities in Early Childhood Teacher Education (see also Palmer 2009, 2010). The data collection that is explored for this study consist of a large number of narrative memory stories about mathematics, written by student teachers in Early Childhood Teacher Education maths courses. When analysing the data I was challenged to transfer myself as researcher from one theoretical field of understanding to another. I found myself in transit between two theoretical territories, which each provided different ways of how to understand how, when and where mathematical subjectivity is constituted. Moreover, the data did not only transform the kind of knowledge that was produced by the analytical work; it also transformed me as researcher.

In the first analysis of the narratives I installed myself in Judith Butler's $(1990,1993,1997)$ theoretical framework and her understanding of the formation of the gendered subject. Butler's thinking on performativity was very productive when investigating the constitution of mathematical subjectivity. It opened up for the idea that being mathematical is not only an inborn essential trait, but is rather always also constituted by performative actions, 
discourse and language. Understanding subjectivity as a result of discursive and performative actions provided an image of subjectivity as multiple, ambivalent, contradictory and in a constant state of change. In line with Butler's theories, the first analysis of the stories focuses on the social interactions between people and how they seemed to be affected by discourse, power and language. In this analysis material objects and places are not specifically noticed as important actors, active in the performativity of mathematical subjectivity. In Butler's theory, matter is understood as discursively constituted or materialised by discourse (1990). It was in the very act of carrying out these first analyses that I began to understand that the narratives included a number of problems and questions that I simply couldn't examine or respond to with the sole support of Butler's theories and performative methodological strategies. Although the stories did include a lot of careful descriptions of social interactions between humans, they did not only portray performative interactions in-between people in discursive practices. It was also possible to identify numerous dynamic descriptions of specific things and places; a hated fill-in-book, a wobbly chair, a staircase in a school building, as well as bodily reactions and emotions such as a headache, a cold sweat or excitement. All of these seemed to matter just as much as social human relationships in the constitution and in the performativity of mathematical subjectivity. Things, places and bodily reactions were forcefully described in the narratives in such a way that materiality seemed to intervene and take action in almost every story. This impact was so great that it was simply impossible for me to ignore that what I had initially considered as lifeless, or simply a background to the intrigues in the stories - the things and the environments - instead played important roles in the plots of many of the stories.

Inspired by Karen Barad's work $(2007,2008)$ and "a turn to the material" (Alaimo \& Hekman 2008, p. 6), my attention was drawn to what Barad calls material-discursive "intra-activity", taking place in-between human and non-human organisms and matter (Barad, 2007, p. 33). Intra-activity is a key element in Barad's thinking and crucial for the understanding of how matter matters for the constitution of subjectivity. Even if Barad's theories don't explicitly focus on subjectification processes, her work can be seen as a contribution to social science that challenges the understanding of the constitution of subjectivity. Barad's theories imply that there is no hierarchal relationship between human and non-human organisms or matter: All matter and organisms are entangled in mutual material-discursive interconnections (Barad, 2007). In this alternative theoretical perspective, subjectivity is not only discursively formed, as in Butler's theories, but is also a result of performative materialdiscursive "intra-activity". The latter analysis of the narratives presented in this article has thus been performed with specific concern to a non-hierarchical and immanent relationship to materiality.

The aim of the article is to investigate how the understanding of subjectivity changes when making a theoretical and methodological transit or re-territorialisation, from a performative and discursive thinking about subjectivity, as suggested by Butler $(1990,1993,1997)$, to a material-discursive agentic realist thinking, as proposed by Barad $(2007,2008)$. I perform an in-depth analysis of one of the stories from my data collection (Ella's story). I begin by analysing the story with Judith Butler's performative and discursive thinking. Then I put to work what Karen Barad calls a diffractive analysis in order to make this transit visible to the reader. Throughout the analysis I also use excerpts from a few of the other narratives in my data collection, to further demonstrate some of the major points in the analysis. In the following sections I discuss in more detail the two theoretical territories. This is followed by a description of the methodological strategies used for the upcoming analysis. The analysis then follows in two subsequent sections. The article is brought to a close with concluding remarks and findings. 


\section{Theory}

\section{A transfer between two different theoretical territories}

As already mentioned in the introduction, the investigation performed for this article has encouraged me to transit, or bring about, what Rosi Braidotti (2006) calls a transposition, inbetween two different theoretical and methodological territories (p. 5-6). The term transposition refers to mobility and cross-referencing between disciplines and discursive levels and indicates an intertextual, cross-boundary or transversal transfer, in the sense of a leap from one code, field or territory to another (ibid. p. 6-7). The first territory I install myself in involves a discursive thinking about the processes when subjectivity is constituted and performative methodological strategies (Butler). The second territory embraces the agentic realist theories of Karen Barad and a diffractive methodological thinking. In this section of the article I write on some of the major differences between these two territories and single out which theoretical tools I have found important for the analysis of the narratives. The theoretical discussion conducted in this section is also closely related to the methodology section that follows. Hence, the two different theoretical standpoints taken in the analysis also influence the two ways in which I have chosen to methodologically approach the data.

\section{The concept of performativity}

Let us begin with the concept of performativity, which is used in Butler's theoretical framework and elaborated on further by Barad. The term performativity - in the way that Butler uses it - illustrates how subjectivities are constituted through iterate repetitions of materialised movements and speech acts in discursive practices (1990, p. 179). Subjectivities are, according to Butler, constituted through recognition, repetition and relations with others in performative processes through discourse and language.

Karen Barad sharpens the theoretical tool of performativity and takes an interest in the agency and intra-activity of matter in this process (Barad, 2007, p. 135-136). By re-working Butler's concept of performativity to include non-human agency, Barad shows that matter and meaning are not separate elements but are entangled and inter-dependent. The starting point for Barad's work is the philosophical framework of quantum physicist Niels Bohr (2007, p. 97-123). Barad uses Bohr's theories when arguing that it is impossible to separate the object of observation from the agencies of observation - the subject, since they are all entangled and agentic. Matter is thus not immutable or passive and is not just a thing or a dead substance [or merely a discursively inscribed object] but is a doing; a congealing of agency (Barad, 2007, p. 139). In Barad's thinking, discourses, organisms (human and nonhuman) and matter are all understood as performative agents (ibid.). Barad writes: "Performativity is not understood as iterative citationality [Butler] but rather iterative intraactivity" (ibid., p. 212). No human and non human body have agency of their own (Hultman \& Lenz, 2010). Although human meaning-making discourse is indeed understood to transform matter, matter itself is not granted active agency or considered mutually agentic in transforming discourse, discursive practices and human subjectivities (ibid. p.6).

Elaborating with the term performativity in Barad's theoretical framework means that new questions can be posed about the constitution of mathematical subjectivity that includes materiality in the world around us. The elaboration of performativity that Barad suggests gives matter its due as an active participant in the world's becoming (Barad, 2003, p. 803). Subjectivity is in this perspective discursive and material and constituted performatively in what emerges in-between the discursive and material. Barad (ibid.) writes:

Matter is not simply "a kind of citationality" (Butler, 1993, p. 15), the surface effect of human bodies, or the end product of linguistic or discursive acts. Material constraints and exclusions and the material dimensions of regulatory practices are important 
factors in the process of materialization. The dynamics of intra-activity entails matter as an active "agent" in its ongoing materialization. (p. 822)

\section{The concept of materialisation}

According to Butler, a discursive practice is a materialisation of powerful discourses that appear as identifiable, knowable and liveable in material bodies and constitute discursively constructed bodies and subjectivity (1993). An example of a discursive practice, in Butler's sense, could be a classroom where all the pupils and the teacher actively - through performative actions and speech acts - materialise a dominant school discourse [1] with certain unspoken and spoken rules and regulations. Butler does not deny the existence of matter but demonstrates its performative productions and enhances the importance of language and discourse. She writes that matter, and the body itself, can be understood as "a process of materialization that stabilizes over time to produce the effects of boundary, fixity, and surface that we call matter (1993, p. 9, emphasis in the original). Butler encourages us to think about matter and the body itself as temporal materialised processes, constituted in language and repeatedly taking place in language (ibid.). Butler (1993) suggests that: "Language and materiality are fully embedded in each other, chiasmic in their interdependency, but never fully collapsed into one another, i.e., reduced to one another and yet neither ever fully exceeds the other." (p. 69) Here she argues that there can be no access to a pure materiality outside or before signification and, by extension, no access to a pure materiality of bodily life that is separate from language (Kirby, 1997, p. 103). A body materialises through repetitive actions and speech acts in discursive practices; it becomes a specific body though performative actions and language. Discourses are, in Butlerian terms, inscribed on the "surface" of bodies, and bodies are transformed and altered by discourse (ibid.).

\section{Intra-activity - Barad's way of elaborating with materialisations}

To understand how Barad $(2007,2008)$ has elaborated Butler's concept of materialisation it is necessary to investigate the concept of intra-activity. Barad uses the concept of intraactivity to provide an understanding of how bodies and things mutually inter-connect in repetitive intra-active relations and thereby influence learning and the production of knowledge (Barad, 2007, p. 149). The concept of intra-activity used by Barad should not to be confused with the modernist notion of inter-activity often used to describe interpersonal relations. Furthermore, intra-activity does not turn our attention to the internal processes in the individual mind, as we might think of it in relation to a psychological discourse. Rather, Barad brings our attention to the agency of the environment, things, materials and places in the ongoing interrelations and mutual processes of transformation emerging in-between human organisms and matter and in-between different matter irrespective of human intervention. Following Barad, the relationship between discourse and the material/the body is mutually caught up in the dynamics of intra-activity $(2007$, p. 152).

By articulating the agency of matter differently, Barad's theories contribute to a rethinking of the materialisations of discourses and discursive practices, as well as of performative subjectivity constitutions, that Butler describes. In Barad's theories, matter and artefacts are to be understood as performative agents in their intra-activities with humans and with each other (2008, p. 140). Thus, in the light of Barad's theories, mathematical and gendered subjectivity can be understood as effects, results or materialisations of performative material-discursive intra-activity that explicitly involve both human and non-human organisms and matter and discourse. In Barad's onto-epistemological and agential realist thinking it's not possible to separate learning from being, or living from culture, since everything is mutually entangled (Barad, 2007, p. 185). In this way of thinking, communication does not only take place between people or organisms, but also inside and 
in-between organisms and bodies, and affects the constitution of subjectivities. In this perspective the subject is not stable, but decentred and "spread out" and, like a flow of energies, constituted in a total inter-dependence with other humans and the matter and physical intensities and forces around us (Hultman \& Lenz Taguchi, 2010). According to Barad's agential realism, there is no hierarchical relationship between different organisms (human and non-human) and the material world around us. The subject is one performative agent among other performative agents and thereby interwoven with the rest of the world.

\section{To sum up the theory section}

The subject is, in Butler's sense, performatively constituted, although at the same time - and as shown in the forthcoming analysis - is also materialised through powerful discourses and language. Barad's project on the other hand is to go beyond the human/non-human divide and to take Butler's thinking about the subject, performativity and materialisation one step further and involve the material (Lykke, 2009, p. 101). Barad illustrates the subject as entangled and intertwined with all the human and non-human organisms the world consists of. The agential realist thinking of Barad holds an understanding of how human existence always co-exists with the rest of the world and with human as well as non-human agents. The subject is discursively and materially embedded in the surrounding world and dissolved and re-grounded in multiple intra-actions.

\section{Methodology}

Two methodological strategies for reading the data

In order to investigate how the understanding of subjectivity changes when transiting from a discursive thinking to a material-discursive in the analysis work, it has been necessary to transfer from one theoretical territory to another. Consequently, I have approached the data from two different theoretical/methodological territories. The first analysis was carried out with the aid of a performative theoretical/methodological thinking inspired by Butler's $(1990,1993,1997)$ work, while and the second was performed with diffractive theoretical/methodological strategies with inspiration from Barad $(2007,2008)$, Donna Haraway (1991) and Karin Hultman and Hillevi Lenz Taguchi (2010).

\section{Performativity as a methodological strategy}

Performativity as a methodological strategy, in relation to Butler's thinking, is used to analyse how subjectivity can be understood, not as a singular "act", but rather as produced by reiterative practice, discourses and speech acts (Loizidou, 2007, p. 41). As Elena Loizidou (ibid.) describes it, performative methodology is about examining discursive practices in order to understand the norms that discursively constitute and materialise the involved subjects. It is about engaging in what the performative does and how it affects the way in which we come to inhabit the world (ibid.). Working with performative methodological strategies has facilitated the identification of the performative materialisations of the school discourse, gender discourses and power play in the narrative memory stories that I have analysed. Particular attention has been paid to the relation between language, discourse and subjectivity. As Butler's account of performativity does not include materiality as such (only as products of discourse and language), I have focused on the performative effects of interpersonal relations, i.e. social relations among friends, teachers, parents; what they say and do and how they adjust to or resist the discursive organisation of time and space.

\section{Diffractive methodology}

Diffractive methodological strategies, as used in the second analysis, is based on how Barad draws on the concept of diffractions (2008, with reference to Haraway, 1991). Diffraction, a concept from physics, can be illustrated by the rolling, pushing and transformation of waves in, for example, the sea, although in physics it can be any kind of waves, like sound-waves 
and light waves (Lykke, 2009, p. 171). A diffractive methodology is like a wave-like motion that takes into account that thinking, seeing and knowing are never done in isolation but are always affected by different material and human forces coming together, or, to use Barad's words; "... knowing is a matter of part of the world making itself intelligible to another part of the world" (Barad, 2007, p. 185). Reading the narratives diffractively is about reading with the data, and to open up for new ways of understanding the data. A diffractive style of reading allows for the researcher to identify all the intra-activities that emerges in-between the researcher and the data. These shifts do not happen completely at random; new directions are marked out in the very intersection between the data, theory, methodology and the researcher. In these diffractive crossroads the original "wave" partly remains within the new wave after its transformation into a new one, and so on, wave after wave (Barad, 2007, 71-83). The new disturbs, intervenes and calls for attention and in this event something new can be created with the data.

A diffractive reading of the data implies that the researcher and the data are entangled and that subjects and objects are mutually constituted. This means that the subjects and the objects (i.e. a myriad mixture of organisms) in the narratives that I investigate are not passive materiality but rather "intertwined agential performances" (Olkowski, 2009, p. 57 with reference to Barad, 2008a). Hence, in the diffractive analysis I have not focused solely on human subjects, their performative actions and talk, but on the intra-activity that emerges in-between human subjects and different matter, learning environments, teaching materials and regulating and power-producing discourses. In these analyses I have tried to rethink matter as activity rather than passive substance, and as agentic in the intra-activity emerging in between all kinds of substances. Thus, I have aspired to read the data in a "flattened out" and non-hierarchal manner (Hultman \& Lenz Taguchi, 2010; Lenz Taguchi, 2010).

\section{Two strategies for collecting data}

The data used in this article derives from two different data sources. The first includes a total of 150 narrative memory stories about mathematics written by 75 Early Childhood Teacher Education students in writing workshops that my colleagues and I arranged in Early Childhood Teacher Education maths courses during the years 2005-2007 (see also Palmer 2009, Lenz Taguchi, 2010). The writing workshops were designed with inspiration from the work of the Australian feminist poststructuralist Bronwyn Davies on "collective biography" (Davies, 2000; Davies \& Gannon, 2006; Davies et al., 2001). [2]

The second collection of narrative memory stories were part of a survey that I conducted with 105 teacher students in general Early Childhood Teacher Education in 2006. One of the questions in the survey was an invitation to write a memory of a situation with significance for the informant's current relation to the school subject of mathematics. These narrative memory stories were written individually and in a more spontaneous and unstructured way than those collected in the writing workshops. Stories from this data collection are used as examples in the analysis section. I have treated the narrative stories (from both data collections) as textual productions that enable me to investigate and illustrate how our understandings change when they are analysed with different theoretical tools. I thus do not consider the stories as true representations of real life or as descriptions of lived experiences in a traditional or taken-for-granted meaning (Davies \& Gannon, 2006). The stories are instead regarded as performative written utterances describing different situations that exemplify how, when and where subjectivity is constituted (ibid.).

\section{Analysis}

The memory story, Ella's story, is outlined below and forms the main story of the analysis. 


\begin{abstract}
Ella's story
I run up the marble stairs in the yellow brick house. There are seventeen steps to the first floor. There are eight fossils in the steps and three flattened pieces of chewinggum. My heart is beating hard in my chest and I can smell the scent of paper and dust in the hallway. There are fourteen other seven-year-old pupils in my class and I'm in the first form. I feel happy today because we've got mathematics on this morning's timetable. The small "fill-in-book" is packed in my bag. I have completed a whole extra chapter at home just to "win" the competition in class today. I suddenly think about Paul; what if he has worked harder than I have? If so I really need to work fast before the lunch-break. How many sums can I do? Do I have my colour pencils with me? I can hear the pencils jangling at the bottom of the bag. Good. That means I can start filling in all the colour tasks in the book. Now I am outside the classroom. Some of my classmates are already standing in a straight line at the door. I hang my bag on my peg and slip into line. The teacher is coming down the corridor. I can hear her shoes clacking against the stone floor. "Good morning everyone", she says. "Good morning Miss", we all answer. The door opens and we run into the classroom. "Now you can start working with your maths books", the teacher says. Silence fills the room. Now and then I hear someone take a breath, giggle or wobble their chair. I try to concentrate and count as fast as I can. I glance at Paul and see that he too is concentrating. He is clutching his pencil, and writing quickly and passionately.
\end{abstract}

\title{
The discursive and performative analysis
}

How is the girl constituted and reconstituted in the local existing and subverting power structures of this particular school, hallway and classroom? What discourses operate in the story, and how are they materialised? In what ways is this girl discursively constituted? The girl seems to have run up these stairs many, many times before and has counted the seventeen steps, the eight fossils and the flattened pieces of chewing-gum. This act can be seen as performative in that her subjectivity as a schoolgirl is constituted by the iterations of this very situation and the repetitive bodily actions in this familiar environment (Butler, 1990). As soon as she enters the yellow brick house and starts running up the stairs strong regulating school discourses work on her body and make her run, count and think in specific ways. Her subjectivity can be understood as both a materialisation and as an effect of these specific regulating school discourses. Using the concept of performativity - in Butler's sense - these discourses can be understood as producers of the girl's subjectivity and a strong regulator of time and space in school. In the performativity of the girl's subjectivity the strong discourse that I have simply called the dominant school discourse is very active. This strong discourse can be identified by expressions like "timetable", "maths books", "fill-inbook", "silence fills the room" and "count as fast as I can", referring to discursive practices of doing school mathematics. Becoming an intelligible subject in school means taking up the discursive meanings embedded in this particular discourse. Performing herself as a proper schoolgirl in line with the dominant meanings of this discourse, the girl completes an entire extra chapter at home, plans how to do the filling-in tasks in her book, slips into line outside the classroom and uses her colour pencils to complete the tasks in the book. By sitting properly on her chair, working in her book and being silent she materialises the school discourse. This powerful discourse is embedded in all of these performative actions of becoming a schoolgirl who performs a compliant mathematical subjectivity. The girl both positions her-self and is positioned by others in the class, the teacher and the discourses at play as a proper schoolgirl who does what she is expected to do (Davies et. al., 2001). 
This schoolgirl can be understood as a performative process of materialisation that stabilises over time (Butler, 1993). Through the repetitive actions that she carries out, day after day, week after week, year after year, running up the stairs, working in her maths book(s), listening to the teacher(s), doing her homework and hanging out with her friends she materialises performatively as this girl. Her subjectivity as a schoolgirl is not given and does not precede her performance, but is practised and constituted in and through her actions, talk and the materialising discourses working in this school (Butler, 1993). Mathematical and gendered subjectivity is constituted by this specific discursive practice by the girl's performative bodily life and the interpersonal interactions with her classmates and the teacher. Her subjectivity can also be understood as a result of speech acts performed in this school context, such as the teacher's utterance: "Now you can start working with your maths books" as well as the courteous greeting procedure in the corridor: "Good morning everyone", she says. "Good morning Miss", we all answer. In Butler's sense, these speech acts form and define the subject in a powerful way (Butler, 1997, p. 23). Importantly, this girl's subjectivity is not stable and constituted once and for all, even if it is repeated and materialised performatively every day in this specific context. As Butler (1995) writes, there is always the possibility for reiteration of conventions or norms (p. 135). Subjectivity must be constituted over and over again as an ongoing performative practice. Even if we think about subjectivity as dispersed and constituted in discourse, it is never stable or solid, but is instead shifting and multiple. This story shows how traditional school discourses makes the position as a proper schoolgirl available, and how this position becomes desirable for this girl. In this context, specific gendered and mathematical subjectivity is constituted in processes of subjectification. Subjectification signifies the process of becoming subordinated by power as well as the process of becoming a subject (Butler, 1995, p. 2). In other words, knowing exactly what to do and what is required of you (like the girl in the story), and at the same time feeling subordinated by powerful discourses (like the school maths discourse with its competitive components), produces feelings of ambivalence and sometimes anxiety. The subjectification process can be understood as discursive and performative and an active coproducer of ambivalent mathematical subjectivity (Palmer, 2009). Butler writes: "Subjection consists precisely in this fundamental dependency on discourses we never chose but that, paradoxically, initiates and sustains our agency. 'Subjection' signifies the process of becoming subordinated by power as well as the process of becoming a subject."(Butler, 1997, p. 2) Other stories in the data collection also illustrate this process. This is how another student teacher remembers a maths lesson:

The solution is appearing on my paper, without problems, and I look up from my place at the back of the classroom. Everybody is still working. Why are they not ready yet? I look at my paper again and I start doubting. "OK", the maths teacher says, "that was not so easy. Do we have any suggestions to the solution?" I don't dare to deliver my solution, even though it seems obviously right. "I guess we have to ask Mike then." Mike, the maths genius of the class, is delivering the answer nonchalantly and the maths teacher explains to the class. I want to scream: That's my solution! I knew that! But I don't say anything and simply watch the others copy the equation from the blackboard. Why didn't I have the courage to answer?

This girl is confident that she knows the answer to this particular question, but does not have the courage to answer. Her feelings are mixed and her mathematical subjectivity can be understood as ambivalent. In this story it is possible to see how the girl positions herself and is positioned by the teacher [and Mike?], as a silent hardworking girl that works on her own. Nobody is aware of the fact that she knows how to solve this mathematical problem. The language that is used in the classroom and the powerful discourses working on the social relations in this room not only constitute mathematical but also gendered subjectivity. This 
girl compares herself to Mike - who is assigned the epithet "maths genius of the class" - and becomes everything he is not, namely, shy, not a genius or a mastermind and not a boy (cf. Palmer, 2009; Walkerdine, 1998).

If we return to Ella's story we can see that gendered discourses, related to mathematics and school performance, can be identified. When connecting this girl's performance to contemporary research about gendered attitudes and mathematics in Western societies, it is possible that she might be performing in a certain way in order to live up to the teacher's gendered expectations in the present discursive context. The now classic studies of Walkerdine (1998), as well as Janet Hyde's (et al., 2008) brand new study, show that teachers expect boys and girls (as stereotyped groups) to act in different ways in mathematics education. Girls are expected to be better at, and more interested in, instrumental work in their maths books, whereas boys are expected to be more innovative and better at problem-solving than girls. Walkerdine (1998) has shown that, in Britain, and especially on the part of teachers, girls' proficiency in mathematics is often considered to be a result of hard work and basic learning, rather than intelligence or 'smartness'. While these stereotypes about boys' and girls' mathematical performances might be seen as oldfashioned, according to Hyde's studies from 2008 they are still prevalent among teachers and parents.[3] The girl in the first story lives up to these gendered expectations as a hardworking girl, even though we don't know anything about the rest of the class, or whether Paul is expected to perform differently than Ella. The construction of mathematics in the Western world, i.e. as a masculine, rational, scientific subject, also interrelates with these expectations of boys and girls (cf. Mendick 2006; Walkerdine, 1998; Ernest, 2004; de Freitas, 2008). The girl in Ella's story can subsequently be understood as an autonomous subject, in that she conforms to the dominant order in the classroom developed by the teacher, the children and (unexpressed) gendered expectations.

So, how and as what do the discourses in this first performative and discursive reading materialise? The discourses identified in this story, namely the school discourse and gendered discourses about girls' and boys' expected mathematical performances, materialise as a traditional maths education in a conventional classroom with ordinary teaching aids and methods. The powerful discourses inform the girls and the boys, as well as the teachers, about how to walk, talk and think performatively in this specific school environment. The children know exactly what will happen in every single minute of the day, e.g. they will sit on their chairs, work in their "fill-in" maths books in silence and (at least seemingly) neither question nor dismiss this way of working. In other words, they adjust and adapt to the present discursive order. This girl's performance of her subjectivity - as a proper schoolgirl - is materialised by the language used in this classroom and the present discourses in this school context.

\section{The material discursive analysis}

When going back to Ella's story, now equipped with Barad's theoretical/methodological tools for understanding, I am completely taken by how the materiality - the fill-in-book, the stair case, and the teachers clacking shoes - intervene and take action in the plot. When reading the narrative diffractively I am totally engaged by the embodied materiality that is incorporated in the plot. The materiality in Ella's story required me to investigate in what ways the matter, organisms and bodies in the story could be significant for the constitution of this girl's subjectivity. In this diffractive methodological work I tried to attend to, and respond to, the material-discursive intra-actions in the story and to investigate how they seemed to matter in the stories. 
Let me start by noting that, in relation to Barad's thinking, there are a lot of different active performative agents involved in the story; a school bag that has been carried to and from school so many times that it has left a mark on the girls shoulder, marble stairs that have been stepped on by wet, dry or muddy shoes, a fill-in-book that has been pushed into an overfull school bag numerous times, a desk with marks from sharp pencils going through the papers, Ella, Paul and the teacher, learning and teaching discourses as well as gendered discourses. In other words, the myriad of interrelations between all the human and nonhuman organisms and discourses in this story influence the girl, structure her and are woven into her subjectivity. Nevertheless, perhaps the most conspicuous matter in the story is the "fill-in-book" that the girl carries to and from school every day and that structures the teaching and learning in the maths classroom. The fill-in-book actively brings the story ahead; the plot is actually set around it. Consequently, in the beginning of my materialdiscursive analysis I will focus especially on the intra-actions in-between the "fill-in-book" and the surrounding agents, human as well as non human, to study how this performative agent interferes with, and intra-acts in, the process of subjectification in maths education.

In line with Barad's thinking, the fill-in-book described in Ella's story is an active performative agent that, together with dominant discourses and other performative agents intra-acts with the girl, such as a staircase, a school bag, eight fossils and a chair. The girl solves all the mathematical problems in her book with increasing excitement as she gets towards the end of the page. Writing neat numbers in the book with a pencil, or using the coloured pencils, can be understood as performative acts of care, almost love, for the craft of printing the mathematical numbers and signs. Human and non-human things, organisms, bodies and the operating discourses can thus be understood as permeated or saturated into each other.

Agency is produced in intimate relations in-between the book, the pencils, the children, the teacher, the architecture and the relevant discourses. According to Barad, agency is a matter of intra-acting; it is an enactment, not something someone or something has (Barad, 2007, p. 214). Agency cannot be designated as an attribute of "subjects" and "objects" (as they do not pre-exist as such) (ibid.). The agency that emerges in-between the book, the pencils and the girl will force the body to handle the present discourse, the school discourse, in specific ways in that it intra-acts with the surrounding environment, administrates the situation and produces and distributes power. This does not mean that power is eliminated in this part of analysis; on the contrary, power is just as much produced in what emerges in the intraactivities in-between material objects, the body, emotions and discourse, which are all understood as equal performative agents. This kind of powerful agency can be identified in many of the stories in my data collection, since more than half of the stories are about the maths book. Here is another short but powerful story about a maths book:

I'm eight years old. It is Friday and it's time for the teacher to tick off the pupils on the list to see who has done this week's tasks in the maths book. I break out in a cold sweat and feel sick. I know that I haven't completed my tasks this week either. Once again the teacher gives me homework to do over the weekend. I feel the tears burning under my eyelids as I pack my maths book in my school bag.

In this context, power is produced in-between the book and other performative agents and discourses: the teacher, the other children, the "tick-schedule", the competitive school discourse as well as discourses regarding spare time and leisure pursuits. Material objects and artefacts can be understood as being part of a performative production of power in an intertwined relationship of intra-activity with other matter and humans (Lenz Taguchi, 2010, p. 4). The maths book transforms both our thinking and our being in a particular space, such as the classroom or at home during the weekend. Together with dominant discourses of 
learning and teaching mathematics, as well as gendered discourses, it also regulates how the teacher moves and talks in the classroom and how she arranges the learning situations and the physical space of the classroom. Barad (2008) writes:

Material conditions matter, not because they "support" or "sustain" or "mediate" particular discourses that are the active factors in the formation of the subjects, but because both discourses and matter come to matter through processes of materialization and the iterative enfolding of phenomena into apparatuses of bodily production (p. 244).

The small "fill-in-book" in the story recounted above and the discourses are all mutually implicated in the dynamics of intra-activity and enfolding that affect the materialisation of the girl's body. This also affects the girl's feelings: she feels anxious, stressed, sad and sick. These emotions make the girl move and think in specific ways, it permeate her body as audible, tactile and visual transformations produced in relation to a specific situation, event or things. Emotional power thus emerges as a kind of force inside and in-between human and non-human organisms and bodies and affects the constitution of subjectivities. This kind of diffractive analysis could have been carried out by focusing other performative agents, for example a school bag, a laptop, a mobile phone or a pocket calculator. Seen from an agential realist and material discursive perspective, a lot of things are involved in the constitution of mathematical subjectivity.

Let us now go back to Ella's story again and further investigate the intra-actions in-between human beings and the materiality. What emerges if we fix our gaze on some of the multiple material-discursive intra-activities that are taking place and what emerges in-between the different performative agents, regardless of whether these are human or non-human? To begin with, in the first part of Ella's story when the girl runs up the marble stairs in the yellow brick house, her running legs and beating heart and the inhaling of the smell of paper and dust can be understood as a mutual state of intra-action with the architecture, the performative agents involved (the school bag, the fill-in-book, the colour pencils, the sums in the book) and the strong regulating discourses of this particular school. The materiality of the marble steps is in dynamic intra-action with the girl's body, forcing her to lift her feet and legs and activating her muscles, which become tense and warm from running up the stairs. The materiality of the staircase also has an effect on the girl's breathing and body temperature, for example as a result of the fast climbing of the many stairs. Everything intraacts: the marble staircase, the stuffy air she breathes, her lungs, the circulation of her blood, the muscles in her legs lifting her feet as she mounts the stairs, and importantly, her strong expectations of what might happen in the maths classroom. There is no clear distinction, or border, between the girl's body and the steps in the hallway, the discourses and the bodily effects of running up the stairs to the maths lesson. In this specific material-discursive event everything is intertwined in the production of subjectivity. Moreover, the discourses do not only come to matter, but matter also comes to matter in the process of becoming a subject (Barad, 2007, p. 393). Thus, the performative processes are not limited to repetitive acts and movements of the girl's body, as we have learnt to understand the concept of performativity in Butler's thinking, but also include the intra-activity between non-human material objects and the girl's body.

Using the concept of performativity in Barad's sense is about articulating matter differently. In a Baradian understanding of performativity, the girl in this story does not only become a girl by discursive performative speech acts or repetitive bodily actions. In this logic, performativity is about a pluralist enactment or doing that includes non-human agencies and thereby turns away from the human-centred vision of the body (Parisi, 2009, p. 79). In this story, the heavy books in the girl's school bag, the stuffy air in the hallway, the mark on her 
shoulder, the veins that distribute her blood to the muscles and the present school discourse all intra-act in the performative processes. No priority is assigned to matter or discourses - it is all intertwined. The girl's body is not separated from the surroundings. Instead, she can be understood as "a set of operational linkages and connections with other things, other bodies" (Grosz, 1994, p. 120). According to an agential realist thinking, the girl in the story is not an individual subject but one fragment or part of the rest of the organic and inorganic environment. The girl's subjectivity is thus intertwined with the stairs, the air in the hallway, the school bag, other children's bodies, sounds, speed and flows of intensities. Without the environment, the scent of the paper and the dust, the beating heart in the girl's chest, the fourteen other seven-year-old pupils, the maths book and the silent classroom, she is not this specific subject. To illustrate this immanent way of thinking about subjectivity further, I provide another story from my data collection in which a schoolgirl can be seen as a fragment or part of the rest of the organic and inorganic environment, rather than an individual subject;

The teacher returns the maths tests. My calculations are correct and my test is exemplary. The teacher has made a copy of my test and shows it to the whole class with support of an $\mathrm{OH}$-projector. My calculations are dancing around on the wall. Many of the boys in the class are dissatisfied with their results and try to convince the teacher that they should have more points. I really enjoy the situation. It feels like a victory that I, as a girl, am the best pupil in class.

In this memory story it is possible to imagine this girl's mathematical, and gendered, subjectivity as interwoven with the environment. The strong light from the $\mathrm{OH}$-projector illuminates the entire wall, the whiteboard and the teacher's hands and face. The event is thick and dense with a multiplicity of emotions, desire, bodies and materiality. The figures, tables and numeric signs from the test seem to float around on the wall and intra-act with the voices of the loud boys, the heat of the $\mathrm{OH}$-projector, the happy sense of being the best pupil in the class and the frustrated feelings of the boys. Gendered and mathematical discourses and matter can be understood as mutually implicated with the environment that produces this girl's specific subjectivity. Subjectivity can be understood as interconnections of all human and non-human organisms in this specific classroom, and as "spread out" and decentred.

In the story about the girl and the $\mathrm{OH}$-projector, moments of intensity and strong emotions can easily be identified (as in the two previous stories). This means moments of intensity, like when the girl in the above story becomes as a beam of light on the wall. She is intertwined with the dancing graphs and signs from the test and is momentarily suspended in an intensity of forces and heat. The entanglements of the girl's body with the surrounding bodies and things helps us to think of this girl being the maths test projected on the wall, rather than a girl who successfully completes her maths test. This is akin to saying that when the girl sits in the classroom and is embraced by the warm light from the OH-projector the light becomes part of her body. In this sense, the girl is not a subject but a set of intensities and movement, or as Dorothea Olkowski (2009) suggest, a "crowd" of intra-acting organs, emotions and perceptions (p. 62). The girl is part of intensity and a degree of heat at a certain time of the day that, together with the surroundings, brings about the girl. The victory she feels - as a girl and being the best pupil in the class - is accompanied by the intensity of the moment.

So, then, what are the implications of a non-unitary vision of subjectivity? When acknowledging the material, the physical body, emotions, imagination and discourses in the subjectivity constitution processes, we do not stand outside of the world. Nor are we simply 
located in particular places in the world, as Barad writes. She continues: "We are, instead, part of the world in its on-going intra-activity" (Barad, 2008, p. 146). The constitution of subjectivity is thus impossible to separate from the discursive, cultural and material learning spaces in which we are constantly engaged. When following this line of thinking, given that we are not separate entities in the world but rather consequences of the world, we can't separate what we are from the world around us (Barad, 2007).

To sum up the complete material-discursive and diffractive analysis section, it's my hope that I have shown that transiting from a discursive and performative theoretical territory to the material-discursive, and trying out new vocabularies and methodological strategies, might facilitate a further investigation of how subjectivity emerges in pedagogical spaces. What I have tried to describe is what Stacy Alaimo and Susan Hekman (2008) has called a "new settlement" of subjectivity. Hereby we can use all we have learned in the linguistic turn but also activate our thinking in relation to how matter matters when we try to understand mathematical subjectivity. Hopefully, this might provide a useful array of concepts for thinking that enables a widened thinking about subjectivity (Blackman, 2008).

\section{Conclusion}

What are the effects of installing oneself as a researcher in a theoretical field and perform an analysis of data with the support of the methodological tools available there? And what new understandings come about when your data encourages you to bring about a theoretical transposition from performative methodological strategies to a diffractive methodological thinking? In this article I have examined how the understanding of mathematical subjectivity changes when transiting from a discursive thinking about subjectivity to a material-discursive and immanent thinking, where matter and meaning are entangled and inter-dependent in the constitution of subjectivity. This transfer from one theoretical territory to another, aided by two different methodological toolboxes, has demonstrated that data can be understood in different ways. In other words, the understanding of data changes depending on where I, as a researcher, install myself, which theoretical tools are available to me, and which methodological strategies I have access to (cf. Lenz Taguchi, 2010). The effect of this theoretical transfer is not that a performative and discursive thinking about subjectivity is disqualified or insufficient. On the contrary, it would seem that the transfer from an exclusive performative and discursive thinking to a material-discursive widens the understanding of mathematical subjectivity and reveals other situations in which subjectivity constitutions are possible. This can consequently be seen as an expansion or opening up to new ways of thinking. It also expands my own theoretical and methodological understandings as a researcher, in that besides noticing the effects of discourse and language in my data I am now also able to observe the multiple material-discursive intraactivities that emerges in-between different performative agents all the time and everywhere.

If we can understand the constitution of mathematical subjectivities in more than one way and adopt a widened perspective, one in which the subject can be seen as interwoven in the physical world around us, what might that mean for the understanding of the myriad of relations we construct towards the subject of mathematics? What would it mean for pedagogical practices? With an expanded perspective on subjectivity constitutions in relation to mathematics, and a transformed methodological gaze that observes the multiple material-discursive intra-activities that are constantly taking place in daily life, we could identify mathematical subjectivity constitutions all around us. In a dance studio, at the football ground, in music class, in-between a girl and three flattened pieces of chewing gum or in the middle of the warm light beamed onto a classroom wall by an ordinary $\mathrm{OH}$ projector. This means that it would become possible to understand subjectivity constitutions 
as something that take place in various situations: in-between zigzagging spaces, discursively and materially embedded in the most ordinary of places and situations. Depending on which questions we pose, what methodological strategies we use, and which theoretical fields we get involved in, we would see and understand this differently. The two territories in which I have installed myself - and transposed in-between - when carrying out this study have provided different centres of attention and different theoretical/methodological understandings.

So, what does it mean to be a researcher in transit? Transposing between different theoretical/methodological territories is an adventure that challenges, not only the way you think, but also the way your body responds and reacts when meeting data. The intensity that is described in the latter analysis is also possible to identify in my own analysis processes. Intra-acting with the shift board, the narrative memory stories, the books on my table, the coffee cup in my hand, the signs and letters that appears on the computer screen - it is all part of the production of me as a researcher writing this article. Hence, research isn't just about investigating what something is and different ways of understanding this. It is about who you yourself are becoming, as a researcher (Redding Jones, 2005, p. 8). In other words, the process of becoming a subject, interlinked with the surroundings, has consequently not only transformed the kind of knowledge that is produced by the analytical work; it also changed me as a researcher. This transit from an exclusive discursive focus to what Barad has called material-discursive intra-activity does not mean that power is eliminated. On the contrary, power is just as much produced in what emerges in the intra-activities in-between material objects used in mathematical learning, the body, affect and discourse, which are all understood as equal performative agents. However, my hope is that this complicated but fascinating struggle with how to understand data from different theoretical perspectives, and with different methodological tools, can help to propel us out of a traditional thinking about research and being (becoming) a researcher. My hope is that the transit I have described in this article can show the way to new theoretical/methodological territories and facilitate new ways of thinking about what research is and can be, as well as a rethinking of the constitution of subjectivity.

\section{Notes}

1. The image of school mathematics, i.e. a culture of traditional textbook-driven teaching and learning, has been investigated by other scholars and is regarded as a common phenomenon in mathematics didactics research, often identified as a discourse of school mathematics (cf. Skovsmose 2006; Brown, Jones \& Bibby 2004; Palmer, 2005, 2009). This discourse is informed by a traditional thinking about how to learn and teach mathematics, how to organise school environments and how to act and talk as a teacher, which has been established as a taken-for-granted discursive practice.

2. Collective memory work is concerned with telling, writing and discussing stories about our own and other people's memories of a specific subject, in this case memories of childhood experiences of mathematics. A collective writing process starts with memories connected to a subject that each member of the group can relate to; in this case childhood experiences of mathematics. After an initial introduction everyone writes about their own particular memory. On meeting up again the participants read their stories aloud and the group shares their written memories with each other. The participants are encouraged to write their memory stories as carefully as they can and include lots of detail, smells, sounds, movements and other information without explanation or clichés. Sharing one's memory story with the group often evokes new memories that help to collectively enrich and develop all the different stories (Davies \& Gannon, 2006, p. 18). "Ella's story" is an example of such a story.

3. According to Hyde's study (et al., 2008) - including SAT results and maths scores from seven million students tested in accordance with the No Child Left Behind Act - cultural beliefs and gendered attitudes, communicated by teachers and parents alike, are crucial when it comes to whether boys and girls regard themselves as "maths smart" or not, and also affect their choice of career and higher education. 
References

Alaimo, S. \& Hekman, S. (eds.) (2008). Material Feminisms. USA: Indiana University Press. Barad, K. (2008a). Queer causation and the ethic of mattering. N. Griffney \& M. J. Hird (eds.) Queering the Non/human, p. 311-338. Aldershot: Ashgate Press.

Barad, K. (2008). Posthumanist performativity: Towards an understanding of how matter comes to matter. Alaimo, S. \& Hekman (eds.) Material feminisms. p. 120-156. USA: Indiana University Press.

Barad, K. (2007). Meeting the universe halfway: Quantum physics of the entanglement of matter and meaning. London: Duke Universal Press.

Blackman, L., Cromby, J., Hook, D., Papadopoulos, D. \& Walkerdine, V. (2008). Creating subjectivities. Subjectivity. 22, 1-27.

Braidotti. R. (2006). Transpositions. Cambridge: Polity Press.

Braidotti, R. (2002). Metamorphoses: Towards a material theory of becoming. Oxford: Polity Press.

Brown, T., Jones, L. and Bibby, T. (2004). Identifying with mathematics in initial teacher training. Mathematics education within the postmodern. Walshaw, M. (eds.), p. 161-180. Connecticut: Information Age Publishing.

Butler, J. (1993). Bodies that matter: On the discursive limits of "sex". London: Routledge.

Butler, J. (1995). For a careful reading. Benhabib, S., Butler, J., Cornell, D \& Fraser, N. (eds.) Feminist contentions: a philosophical exchange. p. 127-143, Oxfordshire/New York: Routledge Falmer.

Butler, J. (1997). The psychic life of power: Theories in subjection. Stanford: Stanford University Press.

Butler, J. (1990). Gender trouble: feminism and the subversion of identity. London: Routledge.

Davies, B. (2000). A body of writing Walnut Creek: AltaMira Press.

Davies, B. \& Gannon, S. (2006). Doing collective biography. The study of everyday lives and their transformation. London: Open University Press.

de Freitas, E. (2008). Mathematics and its other: (dis)locating the feminine. Gender \& Education. 20(3), 281-290.

Ernest, P. (2004). Images of mathematics, values and gender: A philosophical perspective. Mathematics education: Exploring the culture of learning, (eds.) B. Allen \& S. Johnston-Wilder, p. 11-25. New York: Routledge-Falmer.

Grosz, E., (1994). Volatile Bodies: Toward a Corporeal Feminism. Bloomington: Indiana University Press.

Haraway, D. (1991). Simians, Cyborgs, and Women. The reinvention of nature. New York: Routledge.

Haraway, D. (2008). When Species Meet. Minneapolis/London: University of Minnesota Press.

Hultman, K. \& Lenz Taguchi, H. (2010). Challenging anthropocentric analysis of visual data: a relational materialist methodological approach to educational research. International Journal of Qualitative Studies in Education, 23(5), 525-542.

Hyde, J., Lindberg, S-M., Linn, M-C., Ellis, A-B. \& Williams, C. (2008). Gender Similarities Characterize Maths Performance. Science, 321(5888), 494-495.

Kirby, V. (1997). Judith Butler live theory. Continuum international publishing group: London.

Lenz Taguchi, H. (2010). Going beyond the theory/practice divide in early childhood education. Oxfordshire/New York: Routledge Falmer.

Lenz Taguchi, H. (2010a). A material-discursive feminist approach to qualitative research analysis. Paper presented at 7th European Feminist Research Conference June 4-7 2009, Utrecht.

Loizidou, E. (2007). Judith Butler ethics, law, politics. New York: Routledge-Cavendish. 
Lykke, N. (2009). Genusforskning - en guide till feministisk teori, metodologi och skrift. [Gender research - a guide to feminist theory, methodology and writing.] Kina: Liber AB.

Mendick, H. (2006). Masculinities in mathematics. England: Open University Press.

Olkowski, D. (2009). Every 'one'. Nigianni, C. \& Storr, M. (eds.) Deleuze and queer theory. p. 54-71.Edinburgh: Universal Press.

Palmer, A. (2005). Matematik i förändring. [Mathematics in change] Master thesis: Stockholm University.

Palmer, A. (2009). "I am not a 'maths-person"”. Reconstituting mathematical subjectivities in aesthetic teaching practices. Gender \& Education, 4(21), 387-404.

Palmer, A. (2010)."Let's Dance." Theorizing Feminist and Aesthetic Mathematical Learning Practices. Contemporary Issues in Early Childhood, 2(11), 130-143.

Palmer, A. (2010). Att bli matematisk. Matematisk subjektivitet och genus i lärarutbildningen mot de yngre åldrarna. Becoming Mathematical. [Mathematical Subjectivity and Gender in Early Childhood Teacher Education.] Doctoral thesis Stockholm University.

Parisi, L. (2008).The adventures of a sex. Deleuze and queer theory. (eds) Nigianni, C. \& Storr, M., p. 72-91. Edinburgh: Universal Press.

Rhedding-Jones, J. (2005). What is research? Methodological practices and new approaches. Oslo: Universitetsforlaget.

Skovsmose, O. (2006).Travelling through education: Uncertainty, mathematics, responsibility. Rotterdam: Sense Publisher.

Walkerdine, V. (1998). Counting girls out: Girls and mathematics. London: Falmer. 